\title{
ORGANIC WASTE AS A SUBSTRAT IN BIOGAS PRODUCTION
}

\author{
Józefa Wiater ${ }^{1}$, Magdalena Horysz ${ }^{1}$ \\ 1 Department of Environmental Engineering and Protection, Faculty of Civil and Environmental Engineering, \\ Bialystok University of Technology, 45E Wiejska Str., 15-351 Bialystok, Poland, e-mail: j.wiater@pb.edu.pl
}

Received: 2017.05.15

Accepted: 2017.08.01 Published: 2017.09.01

\begin{abstract}
The aim of the study was to demonstrate produced biogas dependence on batch composition as agricultural waste. Research was conducted in biogas power plant Biogas Adler, which was the first agricultural biogas plant built in Podlaskie province. The analysis showed in analyzed biogas production of biogas from waste from agricultural activity, is a good way of their utilization, while producing heat and electricity. Among the three analyzed substrates the highest efficiency of biogas production is characterized by corn silage and manure. Potato pulp significantly reduces the efficiency of biogas production. Independently of the composition and quality of substrates, to produce $1 \mathrm{MWh}$ of the biogas plant consumes approx. $457 \mathrm{~m}^{3}$ of biogas.
\end{abstract}

Keywords: biogas; organic waste; agricultural waste

\section{INTRODUCTION}

Biomass is a biodegradable substance of animal or plant origin (Herbert and Krishnan, 2016). These substances derived from residues and waste from forestry and agricultural production and agri-food industry, as well as from municipal waste management can be used to produce electricity or heat (Kuziemska et al., 2015). For energy purposes the following types of biomass are used: cereal straw, legumes and oilseeds, as well as hay, wood - waste from wood processing industry and forestry, used wood packaging and production, yields of energy crops, dehydrated sewage sludge, pellets, briquettes, bio-carbon, waste from the processing industry, agricultural waste (slurry, manure, plant biomass), waste at municipal landfill, waste from the agro-food industry: beet pulp, bagasse, molasses, wine wastes, oil products waste, with cheese dairies and dairy as well as rotten and expired fruit and vegetables (Kuziemska et al., 2015; Wrzosek and Gworek, 2010).

The direct biomass combustion, gas processing from gasification processing and biogas from the anaerobic fermentation is used for heating. The same substrates after processing are used to produce electricity. In contrast, methanol, etha- nol, hydrogen, and diesel, are used directly as fuel for example in transport. The greatest energy, heat or biogas production efficiency from biomass is achieved at the site of its production, because transport cost of raw materials are ignored. Ecological and economic benefits can be achieved by investing in premises $(50 \mathrm{~km}) \mathrm{re}-$ ceiving systems that ensure negligible energy loss (Wrzosek and Gworek, 2010). In Poland, the amount of biomass that can be exploited for energy purposes, is associated with the accepted model of forestry and agriculture, and also depends on the energy efficiency of crops (Adamczyk et al., 2010). Poland has a large agricultural area, and well developed animal cattery, which creates opportunities for alternative energy sources from biomass development (Horysz et al., 2016). For the production of biogas in the nearest future it is expected to observe an increase in utilization of waste by mixing them in different proportions. Poland's agro-energy potential allows to acquire raw materials enabling biogas production within 5 billion $\mathrm{m}^{3}$ per year. It is assumed that the use at first products from agriculture and waste from the agro-food sector will constitute 1.7 billion $\mathrm{m}^{3}$ of biogas per year (Gołębiewska et al., 2013; Ministerstwo 
Gospodarki, 2010). By the end of the first quarter of 2016 Poland produced with the participation of biomass in the biomass power plants 1,103.115 MW of electricity, while the power of total energy produced by biogas power plants amounted to 217.996 MW (Urząd Regulacji Energetyki, 2016). The use of biomass is beneficial in a condition of stable quality and low price of produced energy or heat (Zawistowski, 2007). Properly localized biomass installation is able to decrease the use of conventional materials reducing greenhouse gas emissions (Herbert and Krishnan, 2016). A significant drawback of the system is the need to provide low economic and environmental losses. For this purpose, there is a need for location logistical develop of equipment for biomass processing, taking into account the place of biomass harvesting, transport and its preparation together with storage (Grzybek, 2007). Biomass material is problematic because of the susceptibility for occurrence of microorganisms and the need to ensure adequate moisture, but properly crafted has high energy potential (Wrzosek and Gworek, 2010). Accordingly, the biogas production in the nearest future is expected to increase the utilization of waste by mixing them in different proportions.

The aim of this study was to indicate the relation between amount of produced biogas and the composition of the batch used to produce it.

\section{MATERIAL AND METHODS}

The study was performed in a real object, which was Adler Biogas - the first biogas plant built in the Podlaskie and opened in the first quarter of 2014 with a generation capacity of $1 \mathrm{MW}$, located on the National Road 19 (Bialystok - Lublin). Biogas plant operates in a continuous system and in order to ensure optimal conditions of the installation the same quality and composition of substrates throughout the year must be provided. A scheme of a biogas plant is shown in Figure 1.

Operation of agricultural biogas plant in Ryboly involves dosing crushed substrate by screw feeder to a digester. Substrates consisting primarily of corn silage, pork, and poultry manure, as well as potato pulp, diluted with water. In addition, the batch can be enriched by overdue food products of plant origin, by-products of industrial distillery and stomach content from meat processing. About $30-35 \mathrm{~m}^{3}$ of substrate is pumped from the first reservoir to the second tank and from the second tank to post-fermentation tank (Figure 2 ). It is assumed that the daily system demand is about 42-44 tons of substrate. Composition can be modified every day, but replaced raw materials must have a proper energy characteristic. The substrates are subjected to anaerobic digestion in the digesters at a temperature of $38-43^{\circ} \mathrm{C}$, which results in biogas production. Within a

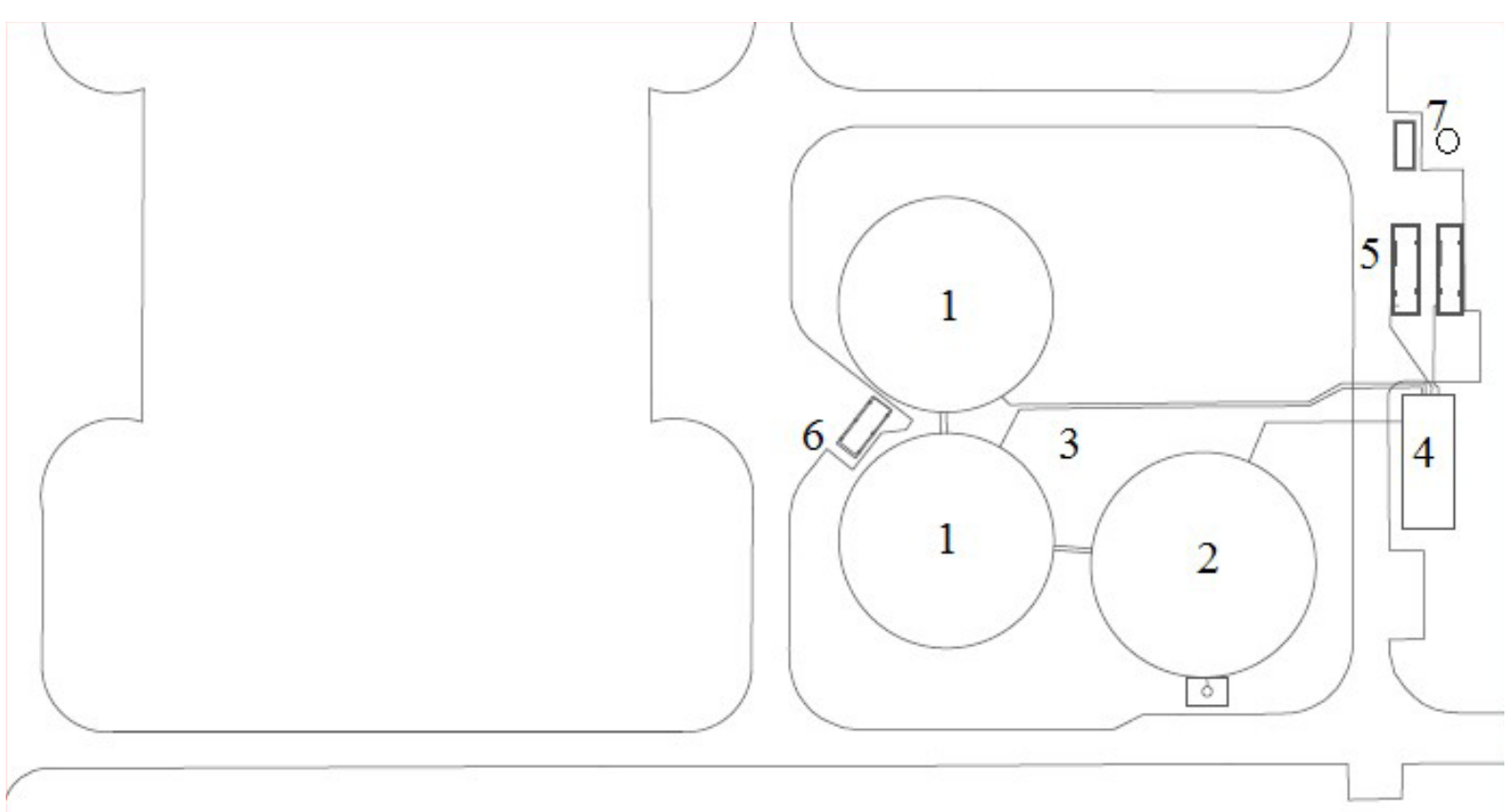

Fig. 1. Scheme of plan site development. 1-digesters, 2-post-fermentation tank, 3-scheme of underground pipes system, 4- technical container 5- co-generators, 6-tank and feed silage, 7-flare 


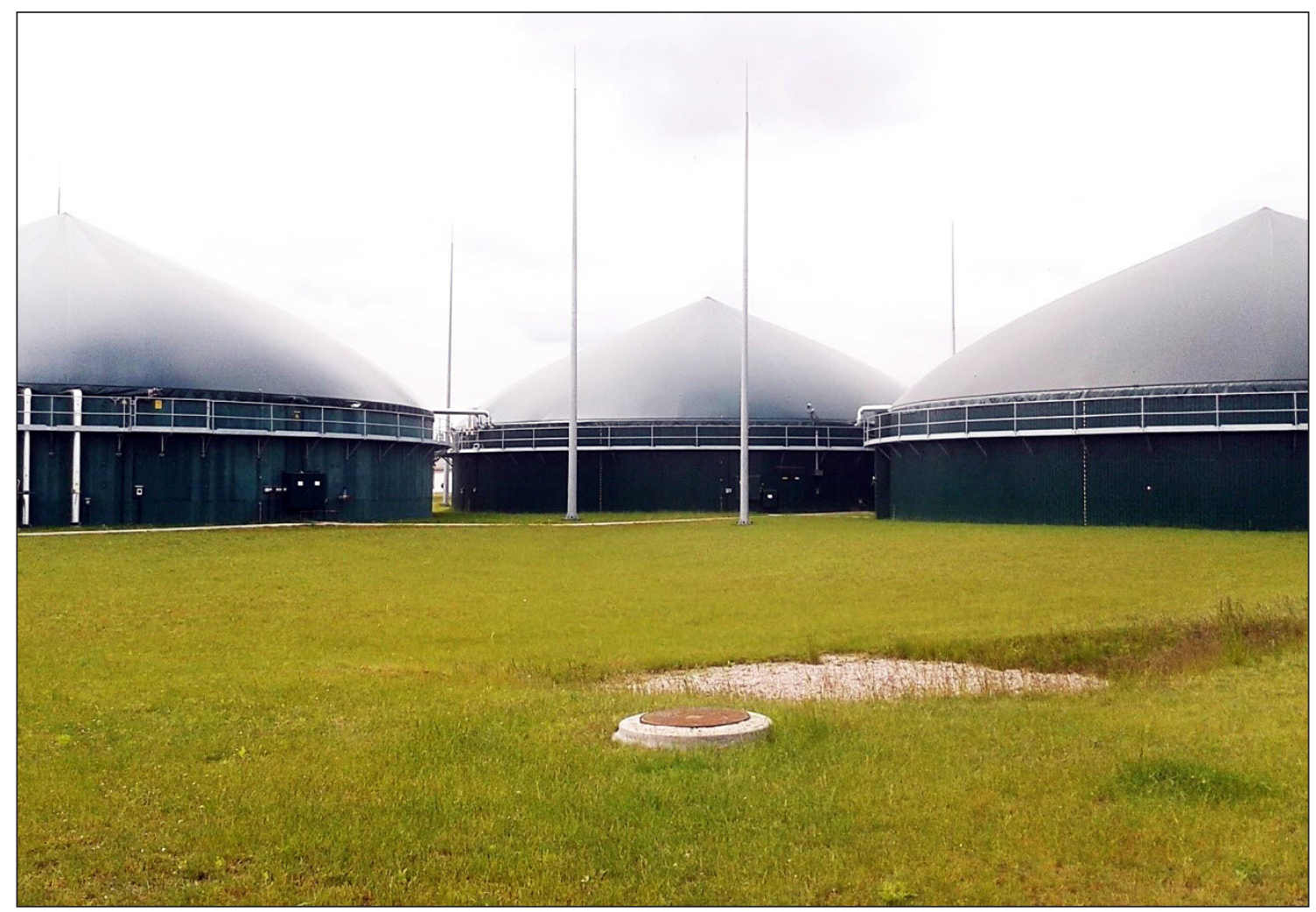

Fig. 2. Adler Biogas power plant

day, the temperature in fermenter may vary by $+/-2{ }^{\circ} \mathrm{C}$. Mixing in the chambers is carried out once an hour for 15 minutes.

The produced biogas consists of approx. $53 \%$ of methane, carbon dioxide and sulphide hydrogen. It is sent by a series of underground pipes to treatment station, where is subjected to dehydration and desulphurization on activated carbon and cooling. So prepared biogas is burned in cogeneration units with a capacity of $600 \mathrm{~kW}$ and $400 \mathrm{~kW}$, to form thermal and electrical energy in result. For energy production biogas power plant consumes $480 \mathrm{~m}^{3} / 1 \mathrm{MWh}$. The produced heat is used for own biogas plant's needs, which amount to about $8 \%$ of total production, while electricity is sold and incorporated into the network of PGE. In addition to the gas processing energy, the product of reaction occurring in the biogas plant are unfermented organic compounds and minerals, so called digestate. This is an organic fertilizer with reduced odor nuisance and with a dry matter content of $8-9 \%$. Digestate from Adler Biogas power plant is used as organic fertilizer for the surrounding agricultural fields. It contains nutrients in the form of easily digestible plant. The whole operating process of agricultural biogas plant of Adler Biogas is controlled by the German system of automatic control created in collaboration of BiogazTech and S.-S.B. Automatisierung.

The basic ingredients used for the production of biogas in Adler Biogas in Ryboly are silage corn, pork and poultry manure (in proportion $3: 1$ ) and potato pulp. The first two substrates come from local farms with an area of 556 hectares (crops and cattery swines) and the Adler area of 321 hectares (crop: corn, canola and cereals). Farms provide the appropriate amount of substrate used to produce biogas. Potato pulp is purchased from potato processing plants PEPEES in Lomza, the company processed annually about 200,000 tons of starch and edible potatoes. The batch is also enriched with minor amounts of other animal or plant components depending on demand. The dry matter content of batch is typically approximately $15 \%$. The fermentation process is controlled by the amount of added salt and regulation of substrates hydration.

The analysis of the amount of produced biogas was based on the proportions of the three batch components (corn silage, manure mixed from swines and poultry, and potato pulp) which were used in the Adler Biogas each month in 2015.

Corn silage was characterized by the percentage of dry matter per ton of the batch at the level of $20-35 \%$. The dry organic matter content 
ranged between $85-95 \%$, while methane production from 1 ton of dry mass amounted to approximately 300 to $700 \mathrm{~m}^{3}$ depending on the quality of the substrate in a particular month. Corn variety dedicated to this purpose, should have a dry matter content of approximately $30-35 \%$ for early variety for late while approximately $28 \%$. It is a decisive factor for on time harvest. A longer period of vegetation resulting in the increase of dry mass per hectare, while the yield dry mass per fresh weight is lower. Depending on the content of organic dry mass corn has a different $\mathrm{C}: \mathrm{N}$ ratio. For dry mass at level of approximately $15 \% \mathrm{C}: \mathrm{N}$ ranges from 30:1 to 35:1, with increase of dry weight ratio of carbon to nitrogen also increases. The optimal ratio of $\mathrm{C}: \mathrm{N}$ is from 10:1 to $25: 1$, because the increase in the amount of carbon in the plant is an increase in the amount of starch, which reduces amount of nitrogen. Preparation of maize for ensilage was based on drying the substrate and the considerable dispersion to approximately 6-7 mm, which increases biogas production. Corn as silage was stored in an airtight shelter from a few to several months. Corn silage compared to other energy plants is characterized by: lower production costs, greater efficiency of biogas production, simple technique of cultivation, harvesting and storage.

Manure from swine is a readily available substrate. Manure has no fixed chemical composition. Manure on average contained $20-25 \%$ dry matter, while the organic dry matter content amounted approximately to $75-80 \%$. It results in generation of approximately $55-65 \mathrm{dm}^{3}$ from 1 $\mathrm{kg}$ wet weight of substrate, and much more, because approximately $270-450 \mathrm{dm}^{3}$ of biogas from $1 \mathrm{~kg}$ of dry organic material. The share of methane in the produced gas from manure varies on average between 55 and $60 \%$. Used manure had a $\mathrm{pH}$ of about 7. It is essential for the use of swine manure to produce biogas or use it for agricultural purposes is adequate $\mathrm{C}: \mathrm{N}$ ratio. This relationship affects the content of nitrogen in digestated. Swine manure is characterized by varying ratio of carbon to nitrogen. The processing of poultry manure in methane fermentation process reduces the odour nuisance and improves the properties of the fertilizer. Poultry manure in Adler Biogas comes from their own poultry farms. Poultry manure includes $30 \%$ of a dry matter per ton of the batch. The sludge dry weight ranges from 70 to $85 \%$ of organic dry mass, methane production from 1 ton of dry organic mass was approximately $260-400$ $\mathrm{m}^{3} / \mathrm{t}$ d.o.m. in resultant biogas methane content ranged from $55-65 \%$. Compared to other substrates, poultry manure is not an easy material to process. A high content of nitrogen (as ammonium) and minerals, excessive amounts of toxic effect on methane fermentation bacteria, thereby inhibiting the production of bio-methane. Potato pulp is organic waste which is disruptive for management of agri-food industry resulting from the processing of potato starch in the potato processing plant PEPEES in Lomza. During the potato campaign lasting approximately 3 months $10-23$ thousand tons of pulp hydrated to $80 \%$ is produced. The substrate consists mainly of raw fibre, residual starch and minerals. During the potato campaign 1600-4200 tons of dry matter is produced on average. Typically, the waste is transferred, as animal feed, and from the manufacture of organic waste are used in the fields as fertilizer. Because of the good properties of fermenting, the substrate is also used as a the batch component for the production of biogas in Adler Biogas, accounting $10 \%$ of the total substrate stored in the plant. The yield of biogas from potato pulp vary between $80-90 \mathrm{~m}^{3} / \mathrm{t}$ d.m., which means $650-750$ $\mathrm{m}^{3} / \mathrm{t}$ d.o.m. In such a biogas methane content is approximately $52-55 \%$. The average dry matter content in raw pulp is approximately $13 \%$.

The equation of estimating the amount of biogas produced from 1 ton of substrates was done with the use of multiple regression based on licensed software Statistica 12.5 in the Polish language version running on Windows 10 . As a measures of equation accuracy, coefficient $\mathrm{R}^{2}$ and the $\mathrm{t}$-Student test were determined.

\section{RESULTS AND DISCUSSION}

Table 1 presents the amount of produced biogas as a function of three substrates feed in the plant was shown. 12827 tons of corn silage was consumed on average per year, and the amount of pork and poultry manure in 2015 amounted 1,560 tons, and 1,221 tons of potato pulp. In total, the biogas plant in order to produce $3594377 \mathrm{~m}^{3}$ of biogas per year used 15608 tons of substrates, each month in a different configuration weight. The amount of produced biogas was $299,531 \mathrm{~m}^{3}$ per month on average and $416 \mathrm{~m}^{3}$ per hour. It has been estimated that from 1 ton of substrates $235 \mathrm{~m}^{3}$ of biogas on average was achieved. Regardless of the month, the share of maize silage 
Table 1. Summary of substrates and biogas yield per month in year 2015 in agricultural biogas plant, Adler Biogas in Ryboly

\begin{tabular}{|c|c|c|c|c|c|c|c|c|c|c|c|c|c|}
\hline & Month & Jan. & Feb. & March & April & May & June & July & Aug. & Sept. & Oct. & Nov. & Dec. \\
\hline \multirow{4}{*}{ 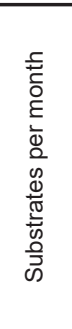 } & $\begin{array}{l}\text { Amount of silage } \\
\text { [tons/month] }\end{array}$ & 1070 & 880 & 910 & 942 & 940 & 930 & 920 & 1190 & 1177 & 1350 & 1278 & 1240 \\
\hline & $\begin{array}{l}\text { Amount of pork } \\
\text { and poultry } \\
\text { manure [tons/ } \\
\text { month] }\end{array}$ & 85 & 135 & 177 & 161 & 152 & 100 & 120 & 110 & 130 & 150 & 120 & 120 \\
\hline & $\begin{array}{l}\text { Amount of potato } \\
\text { pulp[tons/month] }\end{array}$ & 97 & 100 & 110 & 70 & 90 & 90 & 70 & 90 & 50,5 & 110 & 156 & 188 \\
\hline & $\begin{array}{l}\text { Sum of substrates } \\
\text { [tons/month] }\end{array}$ & 1252 & 1115 & 1197 & 1173 & 1182 & 1120 & 1110 & 1390 & 1357,5 & 1610 & 1554 & 1548 \\
\hline \multirow{2}{*}{ 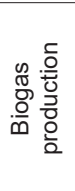 } & $\begin{array}{l}\text { Amount of biogas } \\
\text { produced in month } \\
{\left[\mathrm{m}^{3}\right]}\end{array}$ & 328836 & 311830 & 311190 & 311075 & 325250 & 316030 & 243884 & 304162 & 256568 & 306321 & 280196 & 299035 \\
\hline & $\begin{array}{l}\text { Amount of biogas } \\
\text { from } 1 \text { ton of } \\
\text { substrates }\left[\mathrm{m}^{3}\right]\end{array}$ & 263 & 280 & 260 & 265 & 275 & 282 & 220 & 219 & 189 & 190 & 180 & 193 \\
\hline
\end{tabular}

in a mixture of substrates was greatest. Months in which the amount of maize silage significantly exceeded 1000 tons per month was time after a period of growing, harvesting and ensiling (August-January) of this plant. The average monthly consumption of silage in 2015 amounted 1069 tons /month. The second substrate, which was a part of the batch subjected to methane fermentation, was manure.

The smallest share of manure in the batch was recorded in January, equal to 85 tons/month, and the highest consumption occurred in March and amounted 177 tons/month. On average, in 2015 there were used 130 tons of manure from swines and poultry per month. Potato pulp is the third essential component used in the production of biogas. Its smallest content in the batch was in September, amounting 50.5 tons/month. Most pulp for the production of biogas was used in December (188 tons/month). In 2015, 102 tons of potato pulp on average was used for the production of biogas per month. Changes in the production of biogas appeared even after the slightest movement of the process parameters, and therefore despite of a small share of manure or pulp, compared to corn silage, slight therefore variations have led to significant changes in the biogas production. The relation between the percentage composition of the batch, and the production of biogas was shown in Figure 3. In 2015 the increasing amount of consumed substrate was demonstrated. For months, in which the share of corn silage in the batch was increased, with similar level of other substrates, biogas production was higher. It was noted that the decrease in share of silage replaced by an increased amount of manure in biogas production remains at the lowest level
(February-May). The addition of larger quantities of potato pulp was problematic in substitution of corn silage, because it significantly reduced the amount of biogas (November-December). The largest biogas production in agricultural biogas plant, Adler Biogas was in January and May 2015. Production of biogas in $\mathrm{m}^{3}$ during June decreased comparing to January by $12806 \mathrm{~m}^{3} / \mathrm{month}$.

In February, March and April, the value of produced biogas fluctuated around 311 thousand $\mathrm{m}^{3}$. In August, this value decreased by approximately 2 thousand $\mathrm{m}^{3} /$ month relative to October. In the fourth quarter of 2015 significant lower efficiency of biogas production was observed, because it felt below 300 thousand $\mathrm{m}^{3}$ of biogas per month. The lowest biogas production was observed in July 2015. Table 2 presents the approximate hourly contents of the individual substrates in the batch in tons per hour. In the period of August to December hourly quantity of used substrates was significantly higher than in the first half of the year.

Table 3 shows data of the performance of biogas plants. During the year, the $\mathrm{m}^{3}$ amount of biogas to produce $1 \mathrm{MWh}$ ranged from $442 \mathrm{~m}^{3}$ (in November) to $447 \mathrm{~m}^{3}$ (in February). Most tons of silage to produce $1 \mathrm{MWh}$ were consumed in September and the least in March. In total, the most tons of the batch used to produce $1 \mathrm{MWh}$ were in November and the least in February. The highest energy production in biogas power plant reached in January, and the lowest in July. 1.98 tons of substrates produced $457 \mathrm{~m}^{3}$ of biogas per 12 months on average achieving a production capacity of biogas plants at the level of $0.898 \mathrm{MWh} / \mathrm{h}$ per month, representing an average annual performance of biogas plants amounted $89.8 \%$. 


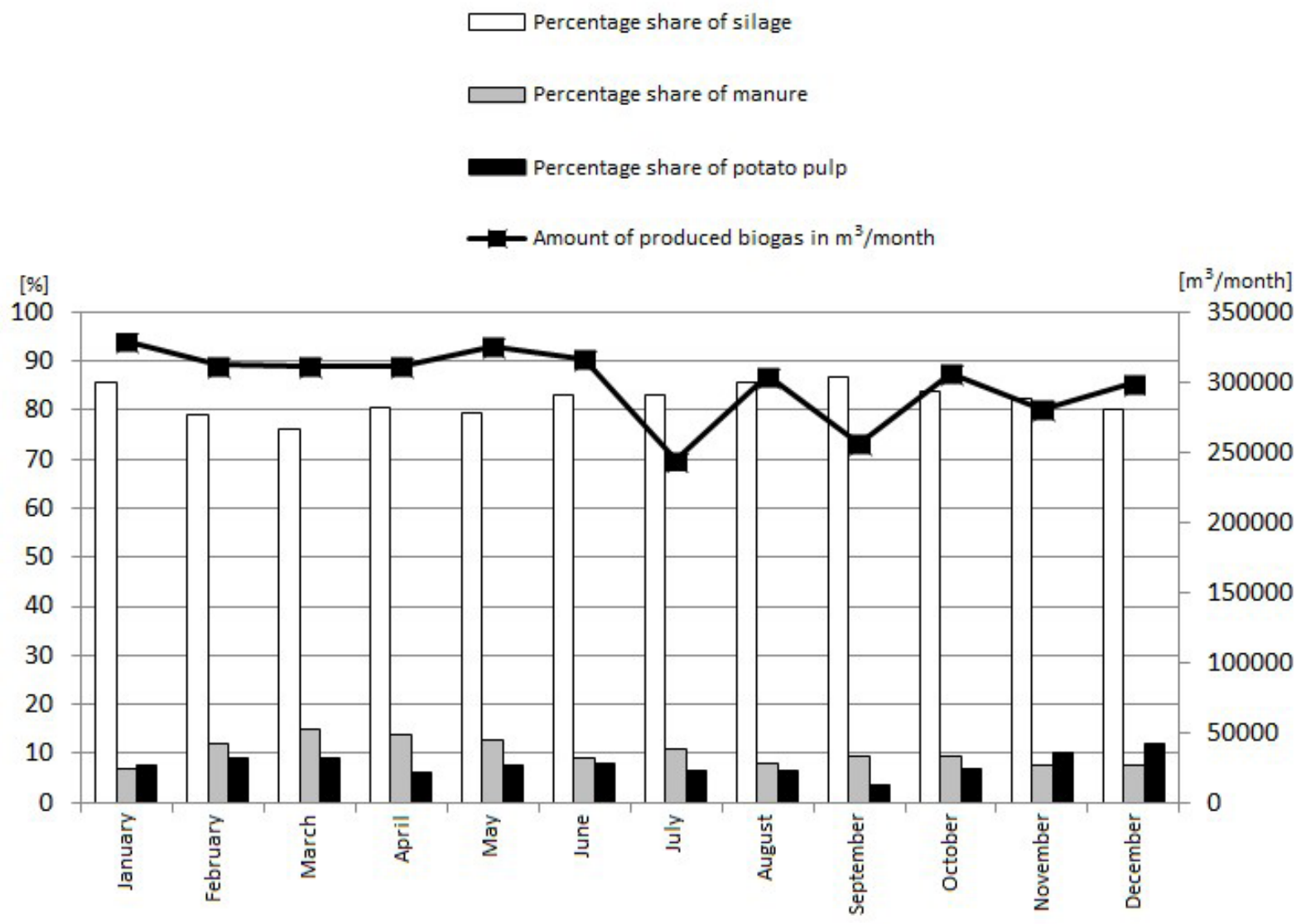

Figure 3. Summary of percentage content of the substrates in the batch and their impact on the amount of produced biogas

Table 2. Summary of approximate hourly batch composition every month

\begin{tabular}{|l|c|c|c|c|c|c|c|c|c|c|c|c|}
\hline \multicolumn{1}{|c|}{ Month } & Jan. & Feb. & March & April & May & June & July & Aug. & Sept. & Oct. & Nov. & Dec. \\
\hline Amount of silage [tons/h] & 1.49 & 1.22 & 1.26 & 1.31 & 1.31 & 1.29 & 1.28 & 1.65 & 1.63 & 1.88 & 1.78 & 1.72 \\
\hline $\begin{array}{l}\text { Amount of pork and poultry } \\
\text { manure [tons/h] }\end{array}$ & 0.12 & 0.19 & 0.25 & 0.22 & 0.21 & 0.14 & 0.17 & 0.15 & 0.18 & 0.21 & 0.17 & 0.17 \\
\hline Amount of potato pulp [tons/h] & 0.13 & 0.14 & 0.15 & 0.10 & 0.13 & 0.13 & 0.10 & 0.13 & 0.07 & 0.15 & 0.22 & 0.26 \\
\hline
\end{tabular}

Table 3. Accuracy measures of the equation

\begin{tabular}{|l|c|c|c|c|}
\hline \multicolumn{1}{|c|}{ Variable in equation } & Variable coefficient & Standard error & t-Student test result & $p$ \\
\hline Free term & 475.52 & 63.40 & 7.50 & 0.0001 \\
\hline Silage & -0.21 & 0.05 & -4.48 & 0.0020 \\
\hline Manure & -0.14 & 0.27 & -0.50 & 0.6305 \\
\hline
\end{tabular}

On the basis of study results, there has been developed a linear relationship between the monthly amounts of each substrates and the amount of biogas produced from 1 ton of mixture exposed on fermentation. The resulting regularity was described by following equation:

$$
B=-0,21 \cdot \mathrm{K}-0,14 \cdot 0+0,06 \cdot \mathrm{W}+475,52
$$

where: $B$-amount of biogas produced form 1 ton of substrates
$K$ - amount of silage [tons/month]

$O$ - amount of pork and poultry manure [tons/month]

$W$ - amount of potato pulp [tons/month]

The values of statistics describing the model are summarized in Table 3 . The variable affecting the equation as statistically significant at $\alpha$ $=0.05$ was the amount of silage used to obtain biogas. Other parameters were characterized by a 
smaller impact on the estimation accuracy of the proposed equation. Among the used variables, the amount of silage was burdened with the smallest standard error. The determination coefficient $\mathrm{R}^{2}$ for obtained dependence was about 0.75 , which suggests a relatively good fit of the equation to the observed values.

Figure 4 contains graphical representation of $\mathrm{R}^{2}$ coefficient. Most values approximated by equation were within the confidence interval which allowed to a good reflection of changes using a linear function.

Biogas is produced from organic matter in anaerobic conditions. Countries whose economies are based on agricultural sector, have a high potential for the development of biogas plants in order to reduce the consumption of conventional fuels, without prejudice to the amount of the produced energy and heat [Arthur et al., 2011].

The results confirm a closer relationship between the amount of biogas and the quality of the batch and its energy content than with its quantity and also depends on the season. Selected substrates for biogas production in agricultural biogas plant of Adler Biogas have good availability, guaranteed yield and the fixed costs of delivery. To achieve the highest efficiency, small biogas plants should have permanent composition of substrate consisting of various ingredients. During the process, appropriate kinetic balance should be maintained in different phases of the process. Methanogenic bacteria are responsible for the fermentation process, which must be provided with adequate environmental conditions because their disruption can cause significant reduction in the efficiency of the conducted process, as it was in case of July 2015. Due to the amount of cellular bound water, various kinds of bacteria require different temperature chambers. In Adler Biogas the temperature conditions are maintained within $38-43{ }^{\circ} \mathrm{C}$, under which according to Appels and others (2008) biogas production is the greatest. Czerwińska and others (2014) claim that water in fermentation mass has a significant effect on microbial growth, structure and properties of the batch. Jędrczak (2008) argues that the moisture content is calculated in relation to the dry organic matter, should not exceed $15 \%$ to ensure its easy transport between installed devices. These conditions in the analysed biogas plants were mostly satisfied, although as the authors say, abundance of water during the process of anaerobic sludge stabilization is changing. Both Jędrczak (2008) and Czerwińska and Kalinowska (2014) argue that to maintain the adequate development of microorganisms, access to basic nutritional compounds should be provided.: ie nitrogen, carbon, phosphorus, sulphur, sodium, iron, magnesium, calcium and potassium. The batch components ensure adequate chemical composition and digestibility of ingredients for mutagenic microorganisms. Among the constituents of a batch, corn silage dominated, primarily because of its availability and the properties

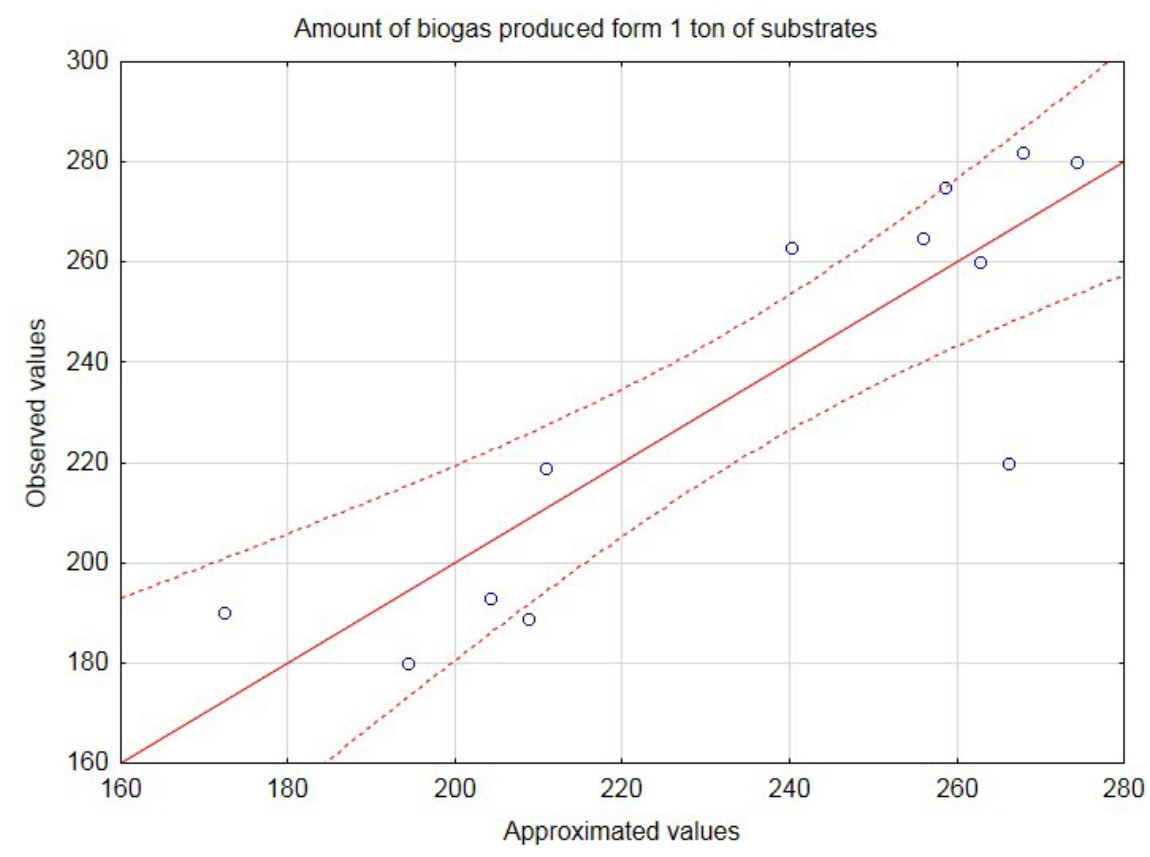

Figure 4. Graphical representation of $\mathrm{R}^{2}$ coefficient 
Table 4. Adler Biogas power plant effectiveness in 2015

\begin{tabular}{|c|c|c|c|c|c|}
\hline Month & $\begin{array}{c}\text { Amount of biogas } \\
\text { used to produce } \\
1 \mathrm{MWh} \text { in } \mathrm{m}^{3}\end{array}$ & $\begin{array}{l}\text { Tons of silage used } \\
\text { to produce } 1 \mathrm{MWh}\end{array}$ & $\begin{array}{c}\text { Tons of substrates } \\
\text { used to produce } \\
1 \mathrm{MWh}\end{array}$ & $\begin{array}{l}\text { Produced energy } \\
\text { in } \mathrm{MWh} / \mathrm{h}\end{array}$ & $\begin{array}{c}\text { Monthly } \\
\text { effectiveness in \% }\end{array}$ \\
\hline January & 453 & 1.47 & 1.72 & 0.976 & 97.6 \\
\hline February & 477 & 1.35 & 1.71 & 0.972 & 97.2 \\
\hline March & 447 & 1.31 & 1.72 & 0.935 & 93.5 \\
\hline April & 461 & 1.40 & 1.74 & 0.937 & 93.7 \\
\hline May & 459 & 1.33 & 1.67 & 0.953 & 95.3 \\
\hline June & 464 & 1.36 & 1.64 & 0.947 & 94.7 \\
\hline July & 471 & 1.78 & 2.14 & 0.696 & 69.6 \\
\hline August & 464 & 1.81 & 2.12 & 0.882 & 88.2 \\
\hline September & 454 & 2.08 & 2.40 & 0.785 & 78.5 \\
\hline October & 448 & 1.98 & 2.36 & 0.918 & 91.8 \\
\hline November & 442 & 2.02 & 2.45 & 0.881 & 88.1 \\
\hline December & 446 & 1.85 & 2.31 & 0.901 & 90.1 \\
\hline
\end{tabular}

of one of the highest power among known substrates subjected to fermentation. The percentage of corn silage in the mixture does not fall below $76 \%$, and the maximum value in 2015 reached up to $85.6 \%$. The amount of manure in batch in 2015 ranged between $6,8-14,8 \%$, while the potato pulp between $7,7-12,1 \%$. Such a mixture has its justification in the energy characteristic of substrates. According to Schattauer and Weiland (2010b) the most energy substrate is maize silage, because using one ton of substrate 170-200 $\mathrm{m}^{3}$ of biogas can be achieved, and the least energetic is manure from swines, where using one ton of ground during methane fermentation can get 20 $-35 \mathrm{~m}^{3}$ of biogas. According to Cukrowski and others (2009) considering only a dry organic matter, it can be concluded that the energy efficiency of corn silage and manure is similar. Thus, the energy content of the product largely depends on the dry matter content in batch. When selecting substrates used for the production of biogas the energy value of the components in raw form needs to be followed, and not the dry matter in the feed due to reduced costs of preparation of raw materials. If the substrate was exposed to a significant treatment before use in order to improve its energy efficiency, the costs of methane fermentation process would raise significantly. Adler Biogas process is aided by mixing batch with mixers in the digester. According to Czerwińska and Kalinowska (2014), properly calculated mixing intensity aims at optimizing the process parameters, such as: preventing the chamber zones of varying concentration and density of the decomposition, accelerates degradation, reduces the amount of sludge formed, so that it is possible to freely escape gas. In contrast, poorly chosen mixing intensity causes cooled and overheated zones occurrence. According to Appels and others (2008) mismatched mixing does not provide adequate processing conditions throughout the volume of the chamber causing the overload zone of the reactor which suppresses the development process of anaerobic bacteria. Setting an appropriate mixing intensity depends largely on the temperature of the fermentation.

The results analysis shows that the best efficiency of agricultural biogas plant has been achieved in the first half of 2015 which may be caused by better weather conditions, among others, more stable temperature than in the second half. It can be clearly stated that the reduction of silage content in batch is justified only with simultaneous increase of manure share. Only in this configuration biogas plant has achieved the second highest biogas production in 2015 , which amounted $325,250 \mathrm{~m}^{3}$ of biogas using the average amount of substrate of 1,182 tons. From the results it can be concluded that lowering the content of silage in batch while increasing the content of pulp, reduces the efficiency of biogas production. In this case, with increasing usage of substrate the amount of biogas does not increase proportionally. Also according to Romaniuk and Domasiewicz (2014), the highest and at the same time increasing potential of raw materials intended for agricultural biogas plants have corn silage and manure. Both of these components increase the calorific value of the batch. Authors claim that the most frequently used mixture of agricultural biogas plants in Poland is a combination of corn silage, slurry and glycerine. 


\section{CONCLUSIONS}

1. Production of biogas from agricultural activity waste is a good way of disposing of these wastes, while producing heat and electricity.

2. Among the three analysed substrates the highest energy material was corn silage from Adler own farm located in the vicinity of the plant.

3. Corn silage, with the same share of pork and poultry manure in batch, also gained from their own farm, ensure biogas production at a high and stable level.

4. Application of potato pulp derived from potato processing plant PEEPES in Lomza, including maize silage and manure, despite the good energy properties of the substrate significantly reduces the efficiency of biogas production.

5. The amount of produced biogas was highest in January $\left(328,836 \mathrm{~m}^{3}\right)$ and in May 2015, and the smallest in July $\left(243,884 \mathrm{~m}^{3}\right)$ and September $\left(256,568 \mathrm{~m}^{3}\right)$.

6. Regardless of the composition and quality of substrates to produce $1 \mathrm{MWh}$, biogas plant consumes approximately $457 \mathrm{~m}^{3}$ of biogas on average.

\section{Acknowledgements}

This study was conducted as a research project S/WBiIŚ/3/2014 in Faculty of Building and Environmental Engineering of BUT and financed by Ministry of Science and Higher Education.

\section{REFERENCES}

1. Adamczyk F., Frąckowiak P., Zbytek Z., Methods of utlization of the solid biomass for energetistic purposes. Part 1. Plant Oils. Agricultural, Horticultural and Forest Engineering, 5, 2010, 2-4 (in Polish)

2. Appels L., Baeyens J., Degreve J., Dewil R., Principles and potential of the anaerobic digestion of waste-activated sludge. Progress in Engergy and Combustion Science, 34, 2008, 755-781

3. Arthur R., Baidoo M. F., Antwi E., Biogas as potential renewable energy source: A Ghanaian case study. Renewable Energy, 36, 2011, 1510-1516.

4. Cukrowski A. Mroczkowski P. Oniszk-Popławska A., Wiśniewski G., Agricultural biogas - production and use, Mazowieck Energy Agency and Renewable Energy Institute, 2009 (in Polish)

5. Czerwińska E., Kalinowska K., Piskier T., Characteristics of electricity and heat production on the example of biogas plant in Nacław. in: Misterska
E. (Ed.), Science-Methodology Review, Education for Security, Part II, Technology, Poznan 2014, 533-544. (in Polish)

6. Czerwińska E., Kalinowska K., 2014. Conditions of conducting of methane fermentation in biogas plant, Agricultural, Horticultural and Forest Engineering, 2, 2014, 12-14 (in Polish)

7. Grzybek A., Logistics of biomass supply for medium and large power plants. (Eds.), Conference materials "Biomass for power generation and heat engineering - opportunities and problems", Warsaw 2007, pp. 51-57 (in Polish)

8. Herbert G. M. J., Krishnan A. U., Quantifying environmental performance of biomass energy. Renewable and Sustainable Energy Reviews, 59, 2016, 292-308.

9. Horysz M., Malinowski Ł., Szatyłowicz E., Skarżyński Sz., Barszczewska I., Woroniecka N., Dąbrowska K., Trybułowski Ł., Piekutin. J., Analysis and determinants of the development of agricultural biogas plants in Podlaskie Voivodeship, In: Skoczko I., Piekutin J., Wysocka M., Załuska M., (Eds.) "Environmental Engineering - Young Eye", Bialystok 2016, pp. 240-261 (in Polish)

10. Jamrozik A., Gas fuels - produced from waste and biomass, as excellent long-term energy storage in: Misterska E. (Ed.), Scientific-methodical review, Education for security, Poznan 2014, pp. 641-649 (in Polish)

11. Jędrczak A., Biological waste processing, Scientific Publishing House PWN, Warsaw 2008 (in Polish)

12. Kuziemska B., Pieniak-Lendzion K., Trębicka J., Wieremej W., Klej P., Alternative sources of energy, Scientific Letters of the University of Natural Sciences and Humanities in Siedlce, Administration and Management, 103, 2015, 99-113 (in Polish)

13. Romaniuk W., Domasiewicz T., Substrates for agricultural biogas plants, Hortpress, Warsaw 2014 (in Polish)

14. Wrzosek J., Gworek B., Biomass in renewable energy, Environmental Protection and Natural Resources, 43, 2010, 104-116 (in Polish)

15. Zawistowski J., Combustion of biomass with low elevated humidity, in: Conference materials "Biomass for power engineering and heating - chances and problems", Warsaw 2007, pp. 58-63.

16. Ministry of Economy, Development directions of agricultural biogas plants in Poland in 2010-2020 (in Polish) http://www.swineeor.pl/media/js/kcfinder/upload/files/Kierunki-Rozwoju-Biogazowni-Rolniczych-w-Polsce-na-lata-2010-2020.pdf (accessed 22.05.6)

17. Power Regulatory Office, Installed Power (MW) (in Polish) http://www.ure.gov.pl/pl/rynki-energii/energia-elektryczna/odnawialne-zrodla-ener/ potencjal-krajowy-oze/5753,Moc-zainstalowanaMW.html (accessed22.05.2016). 